\title{
Should community pharmacies provide COVID-19 screening services?
}

\author{
Ching Siang $\operatorname{Tan}^{1} \mathbb{C}$
}

Published online: 14 August 2020

(c) Springer Nature Switzerland AG 2020

\section{Introduction}

As of 3 June 2020, the World Health Organization (WHO) has reported more than 6 million confirmed cases of coronavirus disease 2019 (COVID-19) and 373,548 confirmed deaths in 216 countries around the world [1]. Recognising the shortage of healthcare facilities in low- and middle-income countries (LMICs) compared with developed countries, LMICs are likely to experience high mortality rates and detrimental effects on the economy [2]. To date, Malaysia has seen the number of COVID-19 cases increase to 7877 , with a death toll of 115 [3]. Since its beginning in December 2019, the manifestations of pneumonia-like symptoms were confirmed to be caused by a novel type of coronavirus closely resembling the viruses that cause severe acute respiratory syndrome and Middle East respiratory syndrome. COVID-19 patients can develop rapidly worsening respiratory failure and acute respiratory distress syndrome [4].

\section{Handling of the COVID-19 pandemic in Malaysian health facilities}

Since 30 January 2020, the Malaysian Ministry of Health $(\mathrm{MOH})$ has upgraded public hospitals and public health laboratories throughout the country to have the capacity to carry out real-time reverse transcriptase-polymerase chain reaction (RT-PCR) tests to detect COVID-19 [5]. As of 29 March 2020, the laboratory capacity in the country was expanded to 25 laboratories nationwide, including 18 $\mathrm{MOH}$ laboratories and 7 private laboratories [6]. Recently, the Ministry of Higher Education and the Ministry of Science, Technology and Innovation have set up 10 additional

Ching Siang Tan

chingsiang9@hotmail.com

1 School of Pharmacy, KPJ Healthcare University College, Lot PT 17010 Persiaran Seriemas, Kota Seriemas, 71800 Nilai, Negeri Sembilan, Malaysia diagnostic laboratories at institutions of higher learning and university teaching hospitals to enhance COVID-19 testing capacity [6]. As of 4 April 2020, there are 43 laboratories and 18 hospitals available across the country that can conduct COVID-19 RT-PCR tests [7].

In Malaysia, RT-PCR tests for COVID-19 are only conducted in symptomatic patients, with samples for testing being taken at health care centres by qualified physicians, which are then transported to the nearby laboratories appointed by the $\mathrm{MOH}$ for further testing. To detect lower respiratory tract infection, samples are collected from the sputum, tracheal aspirate and bronchoalveolar lavage; for upper respiratory tract infection, nasopharyngeal and oropharyngeal swabs are taken. A single negative test result, particularly if the sample was collected from an upper respiratory tract, does not exclude COVID-19, and repeat sampling and testing are required. Taking samples from the lower respiratory tract is strongly recommended in patients with severe or progressive disease [8]. If samples are transported to nearby laboratories for testing for the presence of COVID-19 within $72 \mathrm{~h}$, they are stored at $2-8{ }^{\circ} \mathrm{C}$; if transportation takes longer than $72 \mathrm{~h}$, the samples are stored at $-80^{\circ} \mathrm{C}$ and transported in ice [9].

\section{Introduction of rapid test kits (RTKs)}

With the aim of increasing the number of daily COVID19 tests from 11,500 to 16,500 , the $\mathrm{MOH}$ recently procured 200,000 reliable rapid test kits (RTKs; Standard ${ }^{\mathrm{TM}}$ Q COVID-19 IgM/IgG Duo Test Kit ${ }^{\circledR}$ ) [10] from the manufacturer (SD Biosensor, South Korea) [11]. This Standard ${ }^{\mathrm{TM}} \mathrm{Q}$ COVID-19 IgM/IgG Duo Test Kit ${ }^{\circledR}$ has a sensitivity rate of $84.4 \%$ and specificity rate of $100 \%$, and can be performed at any clinic, hospital or other centre equipped with biosafety cabinets [11]. As this test can be performed anywhere, its use in the national COVID-19 screening programme will not overload the existing 43 laboratories. Compared with RT-PCR tests, RTKs are easier to handle and the testing procedure is safer. Table 1 shows the differences in features between RT-PCR tests and RTKs. 
Table 1 Comparison of features of RT-PCR and RTKs [12-14]

\begin{tabular}{|c|c|c|}
\hline Feature & RT-PCR & RTK \\
\hline Accuracy & Gold standard for COVID-19 testing & Results are relatively less reliable \\
\hline Specificity rate & $100 \%$ & $100 \%$ \\
\hline \multirow[t]{2}{*}{ Sensitivity rate } & \multirow[t]{2}{*}{$100 \%$} & $<100 \%$ \\
\hline & & $\begin{array}{l}\text { Standard }{ }^{\mathrm{TM}} \text { Q COVID-19 IgM/IgG Duo Test Kit (SD Biosensor): } \\
84.4 \%\end{array}$ \\
\hline Test processing time & $24 \mathrm{~h}$ to up to 3 days & Fast results: $\approx 45 \mathrm{~min}$ \\
\hline \multirow[t]{3}{*}{ How the test works } & \multirow[t]{3}{*}{ Detects the presence of the virus' genetic material } & Detects the presence of the immune system response to the virus \\
\hline & & $\begin{array}{l}\text { Immune system responses: present } \geq 4 \text { days after infection; IgM } \\
\text { is an early immune response, while IgG is a delayed immune } \\
\text { response }\end{array}$ \\
\hline & & $\begin{array}{l}\text { Standard }{ }^{\mathrm{TM}} \mathrm{Q} \text { COVID-19 IgM/IgG Duo Test Kit: } 100 \% \text { sensitiv- } \\
\text { ity for IgM } 9 \text { days after exposure, and for IgG } 12 \text { days after } \\
\text { exposure [12] }\end{array}$ \\
\hline Type of sample needed & Nasopharyngeal (nose/throat) swab & Blood sample \\
\hline $\begin{array}{l}\text { Requirements of the } \\
\text { processing site }\end{array}$ & $\begin{array}{l}\text { Special pathogens laboratory; should be a } \\
\text { biosafety level } 2+\text { facility }\end{array}$ & Equipped with biosafety cabinets \\
\hline Cost (range) & Relatively more expensive (\$US60-160) & Relatively much less expensive (\$US8-14) \\
\hline
\end{tabular}

$R T$-PCR reverse transcriptase-polymerase chain reaction, $R T K s$ rapid test kits, $I g M$ immunoglobulin $\mathrm{M}, \operatorname{Ig} G$ immunoglobulin $\mathrm{G}$

\section{Role of community pharmacists in screening and testing for COVID-19}

Currently in Malaysia, COVID-19 screening and testing services are conducted at selected public hospitals and private hospitals. In an effort to extend the testing capacity, community pharmacies could play an important role in COVID-19 screening and testing. Community pharmacists comprise a unique and large body of healthcare professionals who have been trained at universities, work in the retail environment, are knowledgeable about diseases (including viral infections, drugs, and healthcare products), and closely communicate with other health professionals $[15,16]$. Of note, community pharmacies are one of the essential healthcare services allowed to operate amid the 'Movement Control Order' in Malaysia. Currently, there are 2889 community pharmacies in Malaysia, with wide coverage in each state [17].

Community pharmacists are trusted healthcare professionals with established relationships with their patients. Most people live within close proximity to a community pharmacy, which could shorten the travel time to the COVID-19 testing sites, one of the key measures to mitigate virus transmission. Relative to other sites, testing at community pharmacies has the advantage of enhanced accessibility to the public, with extended operating hours and lack of the need for an appointment for consultation [18]. As they have strong relationships with medical providers and hospitals, community pharmacists could refer patients with suspected or positive Covid-19 for further assessment and medical care.

\section{United States community pharmacists are already involved}

Recently in the US, the Department of Health and Human Services has authorised community pharmacists to order and conduct COVID-19 tests, including serology tests [19]. Notably, the serology tests are solely used to detect antibodies to the virus and are less complex to be conducted relative to molecular tests [20]. 'Drive-up' testing with patients remaining in their cars during the evaluation is one of the suggested proper precautionary methods for performing COVID-19 testing in the US [21]. During this pandemic, the American Pharmacists Association has been giving very encouraging support to US community pharmacists by providing information regarding the Medicare and Medicaid Programs, policy and regulatory revisions in response to the COVID-19 public health emergency, and weekly webinar training and updates in addressing the COVID-19 crisis [22]. As healthcare professionals in primary care, community pharmacists in Malaysia are also well-positioned to aid in the expanded COVID-19 testing programme made possible by the governments' procurement of RTK. For example, community pharmacies could set up 'drive through' COVID-19 testing sites in front of their premises, where community pharmacists and assistants would perform the RTK tests. 


\section{Take home messages}

- At present, RT-PCR and antibody testing (RTK) are the predominant ways to test for COVID-19, and have different sensitivities, handling procedures and results.

- The screening rate in Malaysia is relatively low, with 11,500 COVID-19 tests per day in 43 national laboratories [11].

- In the US, community pharmacists have shown that pharmacy-based testing services are acceptable to the healthcare system. However, the concept of Malaysian community pharmacies testing for COVID-19 has not yet been suggested or implemented.

- Thus, a feasibility study on COVID-19 screening and testing services by using RTKs in community pharmacies, based on the concept of a drive-through service without entering the premises, should be conducted in Malaysia.

\section{Declarations}

Funding No specific funding was received for this work.

Conflict of interest Tan Ching Siang declares no competing interests.

\section{References}

1. World Health Organization. Coronavirus disease (COVID-19) pandemic. 2020. https://www.who.int/emergencies/diseases/novel -coronavirus-2019. Accessed 29 May 2020.

2. Khadka S, Hashmi FK, Usman M. Preventing COVID-19 in low- and middle-income countries. Drug Ther Perspect. 2020;36(6):250-2.

3. Worldometers. Coronavirus Cases. 2020. https://www.worldomete rs.info/coronavirus/country/malaysia/. Accessed 3 Jun 2020.

4. Goh KJ, Choong MC, Cheong EH, et al. Rapid progression to acute respiratory distress syndrome: review of current understanding of critical illness from COVID-19 infection. Ann Acad Med Singap. 2020;49(3):108-18.

5. The Star. 12 public hospitals and public labs equipped to test for virus. 2020. https://www.thestar.com.my/news/natio n/2020/02/10/12-public-hospitals-and-public-labs-equipped-totest-for-virus. Accessed 17 Apr 2020.

6. Ministry of Health Malaysia. Updates on the coronavirus disease 2019 (Covid-19) situation in Malaysia. Press Statement 2020. 2020. https://covid-19.moh.gov.my/terkini/032020/situasi-terki ni-29-mac-2020/68A\%2520Kenyataan\%2520Akhbar\%2520K PK\%2520COVID-19\%2520(29\%2520Mac\%25202020)\%2520v 1\%2520-\%2520EN.pdf. Accessed 9 Jun 2020.

7. Murugesan M. Dr Noor Hisham: Malaysia's testing processes adequate. The Star. 2020. Available at: https://www.nst.com.my/ news/nation/2020/04/581242/dr-noor-hisham-malaysias-testingprocesses-adequate. Accessed 8 Jun 2020.

8. Ministry of Health Malaysia. Garis Panduan Pengurusan COVID19 di Malaysia No.5/2020. Kuala lumpur. 2020. http://covid-19. moh.gov.my/garis-panduan/garis-panduan-kkm. Accessed 8 June 2020.

9. Ministry of Health Malaysia. Guidelines on Ministry of Health (COVID-19): Annex 5b Laboratory testing for patients. 2020. https://covid-19.moh.gov.my/garis-panduan/garis-panduan-kkm/ Annex_5b_Laboratory_Testing_for_Patients_22032020.pdf. Accessed 10 Jun 2020.

10. SD Biosensor. STANDARD Q COVID-19 IgM/IgG Duo. 2020. https://sdbiosensor.com/xe/product/12513. Accessed 10 Jun 2020.

11. The Star. Health DG: New Covid-19 rapid test kits procured from South Korea. 2020. https://www.thestar.com.my/news/natio n/2020/04/16/health-dg-new-covid-19-rapid-test-kits-procuredfrom-south-korea. Accessed 16 Apr 2020.

12. Zainol Rashid Z, Othman SN, Abdul Samat MN, et al. Diagnostic performance of COVID-19 serology assays. Malays J Pathol. 2020;42(1):13-21.

13. Magsambol B. FAST FACTS: What's the difference between PCR, rapid antibody tests? 2020. https://www.rappler.com/newsb reak/iq/261869-things-to-know-polymerase-chain-reaction-rapid -anti-body-tests. Accessed 11 June 2020.

14. World Health Organization. Advice on the use of point-of-care immunodiagnostic tests for COVID-19. 2020. https://www.who. $\mathrm{int} /$ news-room/commentaries/detail/advice-on-the-use-of-point -of-care-immunodiagnostic-tests-for-covid-19. Accessed 12 June 2020.

15. Benrimoj SI, Frommer MS. Community pharmacy in Australia. Aust Health Rev. 2004;28(2):238-46.

16. Khan Z, Muhammad K, Ahmed A, et al. Coronavirus outbreaks: prevention and management recommendations. Drug Ther Perspect. 2020;36(5):215-7.

17. Malaysian Pharmaceutical Society. Analysis report: distribution of poison license a holders and community pharmacies in Malaysia. 2019. https://www.mps.org.my/newsmaster.cfm?\&menui $\mathrm{d}=37 \&$ action=view\&retrieveid=7732. Accessed 16 Apr 2020.

18. Eades CE, Ferguson JS, O'Carroll RE. Public health in community pharmacy: a systematic review of pharmacist and consumer views. BMC Public Health. 2011;11(1):582.

19. U.S. Department of Health \& Human Services. HHS Statements on Authorizing Licensed Pharmacists to Order and Administer COVID-19 Tests. 2020. https://www.hhs.gov/about/ news/2020/04/08/hhs-statements-on-authorizing-licensed-pharm acists-to-order-and-administer-covid-19-tests.html. Accessed 16 Apr 2020.

20. American Pharmacists Association. Pharmacists' Authority to Test for COVID-19. 2020. Available at: https://www.pharmacist .com/sites/default/files/audience/APhACOVID-19PharmacistsAu thority0420_rev_web.pdf. Accessed 15 Jun 2020.

21. Chen SW. Commentary: Pharmacists can do more on frontlines of COVID-19 fight. channelnewsasia.com. 2020. https://www.chann elnewsasia.com/news/commentary/covid-19-coronavirus-whatpharmacists-are-doing-healthcare-12639862. Accessed 15 Jun 2020.

22. American Pharmacists Association. Pharmacists' Guide to Coronavirus. 2020. https://www.pharmacist.com/coronavirus/resou rces-training. Accessed 15 Jun 2020. 